\title{
Integration of nitrogen dynamics into the Noah-MP land surface model v1.1 for climate and environmental predictions
}

\author{
X. Cai ${ }^{1, a}$, Z.-L. Yang ${ }^{1}$, J. B. Fisher ${ }^{2,3}$, X. Zhang ${ }^{4}$, M. Barlage ${ }^{5}$, and F. Chen ${ }^{5}$ \\ ${ }^{1}$ Department of Geological Sciences, The John A. and Katherine G. Jackson School of Geosciences, The University of Texas \\ at Austin, Austin, Texas, USA \\ ${ }^{2}$ Jet Propulsion Laboratory, California Institute of Technology, Pasadena, California, USA \\ ${ }^{3}$ Joint Institute for Regional Earth System Science and Engineering (JIFRESSE), University of California at Los Angeles, \\ Los Angeles, California, USA \\ ${ }^{4}$ Joint Global Change Research Institute, Pacific Northwest National Laboratory and University of Maryland, College Park, \\ Maryland, USA \\ ${ }^{5}$ Research Applications Laboratory, National Center for Atmospheric Research, Boulder, Colorado, USA \\ anow at: Department of Civil and Environmental Engineering, Princeton University, Princeton, New Jersey, USA
}

Correspondence to: Z.-L. Yang (liang@jsg.utexas.edu)

Received: 11 April 2015 - Published in Geosci. Model Dev. Discuss.: 27 May 2015

Revised: 12 October 2015 - Accepted: 11 December 2015 - Published: 15 January 2016

\begin{abstract}
Climate and terrestrial biosphere models consider nitrogen an important factor in limiting plant carbon uptake, while operational environmental models view nitrogen as the leading pollutant causing eutrophication in water bodies. The community Noah land surface model with multiparameterization options (Noah-MP) is unique in that it is the next-generation land surface model for the Weather Research and Forecasting meteorological model and for the operational weather/climate models in the National Centers for Environmental Prediction. In this study, we add a capability to Noah-MP to simulate nitrogen dynamics by coupling the Fixation and Uptake of Nitrogen (FUN) plant model and the Soil and Water Assessment Tool (SWAT) soil nitrogen dynamics. This model development incorporates FUN's state-of-the-art concept of carbon cost theory and SWAT's strength in representing the impacts of agricultural management on the nitrogen cycle. Parameterizations for direct root and mycorrhizal-associated nitrogen uptake, leaf retranslocation, and symbiotic biological nitrogen fixation are employed from FUN, while parameterizations for nitrogen mineralization, nitrification, immobilization, volatilization, atmospheric deposition, and leaching are based on SWAT. The coupled model is then evaluated at the Kellogg Biological Station - a Long Term Ecological Research site within the US Corn Belt. Results show that the model performs well
\end{abstract}

in capturing the major nitrogen state/flux variables (e.g., soil nitrate and nitrate leaching). Furthermore, the addition of nitrogen dynamics improves the modeling of net primary productivity and evapotranspiration. The model improvement is expected to advance the capability of Noah-MP to simultaneously predict weather and water quality in fully coupled Earth system models.

\section{Introduction}

Over the past several decades, eutrophication - high concentrations of nutrients in freshwater bodies leading to severe oxygen depletion from the resultant algal blooms - has become a worldwide problem facing river, lake, and coastal waters (Conley et al., 2009; Howarth et al., 2006). As one of the greatest threats to freshwater and coastal ecosystems, eutrophic conditions lower biotic diversity, lead to hypoxia and anoxia, increase the incidence and duration of harmful algal blooms, and change ecological food webs that reduce fish production (Diaz and Rosenberg, 2008; National Research Council, 2000). These eutrophic conditions are attributed to excessive fertilizer leaching in river basins (Boesch et al., 2009; Boyer et al., 2006). To complicate this further, climate variation and climate change also determine the variation of 
hypoxia extent (Donner and Scavia, 2007): higher temperatures may extend the thermal stratification period and deepen the thermocline, thereby resulting in the upwelling of nutrients from sediment and increasing the concentration of nutrients in the bottom layer of water in lakes (Komatsu et al., 2007). Further, higher precipitation produces more runoff, and very likely more nutrients are delivered to the ocean as well (Donner and Scavia, 2007).

Nitrogen $(\mathrm{N})$ is recognized as the leading nutrient causing eutrophication. Without human interference, $\mathrm{N}$ cycling is relatively slow, as most ecosystems are efficient at retaining this in-demand nutrient. $\mathrm{N}$ enters soil regularly either through atmospheric wet and dry deposition or through atmospheric $\mathrm{N}_{2}$ fixation by microorganisms (occurring mostly in legume plants). $\mathrm{N}$ taken up by plants is confined to relatively slow processes (e.g., growth, decay, and mineralization); in some regions or during the growing season, $\mathrm{N}$ may also limit plant growth, which reduces carbon sequestration over land (Fisher et al., 2012). In addition, N cycling produces nitrous oxide $\left(\mathrm{N}_{2} \mathrm{O}\right)$, which is considered one of the important greenhouse gases responsible for climate warming. These facts make the $\mathrm{N}$ cycle important for studying the response of the climate to the elevated greenhouse gas concentrations. With human tillage of soils, mineralization and nitrification of $\mathrm{N}$ are amplified, which results in the reduction of N storage in soil (Knops and Tilman, 2000; Scanlon et al., 2008). In addition, a large amount of $\mathrm{N}$ fertilizer is applied in specific areas within a short period of time; as a result, a massive excess of $\mathrm{N}$ is leached to the aquatic systems through discharge and erosion, which contributes to the eutrophication in aquatic systems.

Many of these $\mathrm{N}$ processes have been included in land surface, hydrologic, and water quality models developed particularly for environmental, climate, and agricultural applications (Bonan and Levis, 2010; Dickinson et al., 2002; Fisher et al., 2010; Kronvang et al., 2009; Schoumans et al., 2009; Thornton et al., 2007; Wang et al., 2007; Yang et al., 2009). These developments are still in their infancy, and large-scale climate models lack $\mathrm{N}$ leaching parameterizations that are comparable to those used in water quality models. Thus, large-scale models are not feasible for inherently fine-scale applications such as agricultural fertilization management and water quality prediction. Therefore, the present study improves these weaknesses by incorporating the strength of agriculture-based models into large-scale land surface models (LSMs).

The community Noah LSM with multi-parameterization options (Noah-MP) (Niu et al., 2011; Yang et al., 2011) is used as an exemplar of LSMs because it is the nextgeneration LSM for the Weather Research and Forecasting (WRF) meteorological model (Rasmussen et al., 2014) and for the operational weather and climate models in the NOAA/National Centers for Environmental Prediction. Because Noah-MP has an interactive vegetation canopy option - which predicts the leaf area index (LAI) as a function of light, temperature, and soil moisture - it is logical to augment this scheme with $\mathrm{N}$ limitation and realistic plant $\mathrm{N}$ uptake and fixation. The state-of-the-art vegetation $\mathrm{N}$ model is the Fixation and Uptake of Nitrogen (FUN) model of Fisher et al. (2010), which is embedded into the Joint UK Land Environment Simulator (JULES) (D. B. Clark et al., 2011) and the Community Land Model (CLM) (Shi et al., 2016). Modeling the impacts of agricultural management (e.g., fertilizer use) on $\mathrm{N}$ leaching is the strength of the Soil and Water Assessment Tool (SWAT) (Neitsch et al., 2011). Therefore, this study incorporates into Noah-MP both FUN's strength in plant $\mathrm{N}$ uptake and SWAT's strength in soil $\mathrm{N}$ cycling and agricultural management.

Our objective is to develop and utilize a land surface modeling framework for simultaneous climate (carbon) and environmental (water quality) predictions. We first describe the nitrogen dynamic model which combines equations used in FUN and SWAT. We then focus on evaluating the new integrated model at a cropland site, because fertilizer application on croplands globally contributes approximately half of the total $\mathrm{N}$ input to soil, with the other half coming from natural processes (i.e., atmospheric deposition and biological $\mathrm{N}$ fixation) (Fowler et al., 2013; Gruber and Galloway, 2008). Furthermore, cropland is a major source of $\mathrm{N}$ loading in water bodies. We evaluate the new model against observed soil moisture content, concentration of soil nitrate, concentration of nitrate leaching from soil bottom, and annual net primary productivity (NPP). We then analyze the impacts of the addition of $\mathrm{N}$ dynamics on the carbon and water cycles. To guide the use of this model on regional scales, we also analyze the impacts from different fertilizer application scenarios. Finally, we discuss other model behaviors, i.e., $\mathrm{N}$ uptake from different pathways and the major soil nitrate fluxes.

\section{Models, data, and methods}

\subsection{Noah-MP}

The Noah-MP model was augmented from the original Noah LSM with improved physics and multi-parameterization options (Niu et al., 2011; Yang et al., 2011), based on a stateof-the-art multiple-hypothesis framework (M. P. Clark et al., 2011). Noah-MP provides users with multiple options for parameterization in leaf dynamics, canopy stomatal resistance, soil moisture factor for stomatal resistance, and runoff and groundwater. Until this work, Noah-MP did not include any $\mathrm{N}$ dynamics. The only $\mathrm{N}$-related parameterization is in the calculation of the maximum rate of carboxylation ( $V_{\max }$, Eq. 1) - an important factor in estimating the total carbon assimilation (or photosynthesis) rate (Niu et al., 2011):

$V_{\max }=V_{\max 25} a_{v \max }^{\frac{T_{v}-25}{10}} f(N) f\left(T_{v}\right) \beta$,

where $V_{\max 25}$ is the maximum carboxylation rate at $25^{\circ} \mathrm{C}$ $\left(\mu \mathrm{mol} \mathrm{CO} \mathrm{CO}_{2} \mathrm{~m}^{-2} \mathrm{~s}^{-1}\right), a_{v \max }$ is a temperature-sensitive pa- 
rameter, $f\left(T_{v}\right)$ is a function that mimics the thermal breakdown of metabolic processes, $f(N)$ is a foliage nitrogen factor $(f(N) \leq 1)$, and $\beta$ is the soil moisture controlling factor. Since there were no $\mathrm{N}$ dynamics in the model, $f(N)$ was set as a constant 0.67 , which translates to a constant $33 \%$ of $V_{\max }$ down-regulation due to $\mathrm{N}$ stress. This factor was originally used in Running and Coughlan (1988) and adapted into LSMs by Bonan (1991).

Our modifications to the original Noah-MP mainly concern the sub-models dealing with dynamic leaf and subsurface runoff. The dynamic leaf option is turned on to provide NPP and biomass to the newly coupled $\mathrm{N}$ dynamic submodel. In the original Noah-MP model, subsurface runoff from each soil layer was not an explicit output, but it is now a new output in the updated model. However, $\mathrm{N}$ concentrations are different among soil layers, which affects the amount of $\mathrm{N}$ removed from each soil layer by subsurface runoff. Therefore, in conjunction with the runoff scheme options 1 (TOPMODEL with groundwater) and 2 (TOPMODEL with an equilibrium water table), the lumped subsurface runoff for all four layers is first calculated, and then the water is removed from each soil layer weighted by hydraulic conductivity and soil layer thickness.

\subsection{Nitrogen dynamics}

In Noah-MP, the soil $\mathrm{N}$ model structure is the same as in SWAT, which includes five N pools consisting of two inorganic forms $\left(\mathrm{NH}_{4}^{+}\right.$and $\left.\mathrm{NO}_{3}^{-}\right)$and three organic forms (active, stable, and fresh pools). The $\mathrm{N}$ processes employed from SWAT are mineralization, decomposition, immobilization, nitrification, denitrification, and atmospheric deposition. The $\mathrm{N}$ processes employed from FUN are uptake and symbiotic biological $\mathrm{N}$ fixation, which can be further divided into active and passive soil $\mathrm{N}$ uptake, leaf $\mathrm{N}$ retranslocation, and symbiotic biological $\mathrm{N}$ fixation. Figure 1 shows the flow chart of the nitrogen dynamic model. In this section, we describe the core equations. The full description for plant $\mathrm{N}$ uptake and soil $\mathrm{N}$ dynamics is available in Fisher et al. (2010) and Neitsch et al. (2011), respectively. Table 1 shows the model input variables and parameters. Most of these parameters use the values recommended by Fisher et al. (2010) and Neitsch et al. (2011), while some of them are adjusted to best represent the site condition and hence match site observation. The important adjusted parameters include the $\gamma_{\mathrm{sw}, \text { thr }}$ (threshold value of soil water factor for denitrification to occur), $\beta_{\min }$ (rate coefficient for mineralization of the humic organic nitrogen), and $\beta_{\text {rsd }}$ (rate coefficient for mineralization of the fresh organic nitrogen in residue).

\subsubsection{Nitrogen uptake and fixation}

Plant $\mathrm{N}$ uptake and fixation follow the framework of Fisher et al. (2010), which determines $\mathrm{N}$ acquired by plants through Eq. (3), advection (passive uptake); Eq. (4), symbiotic bi-

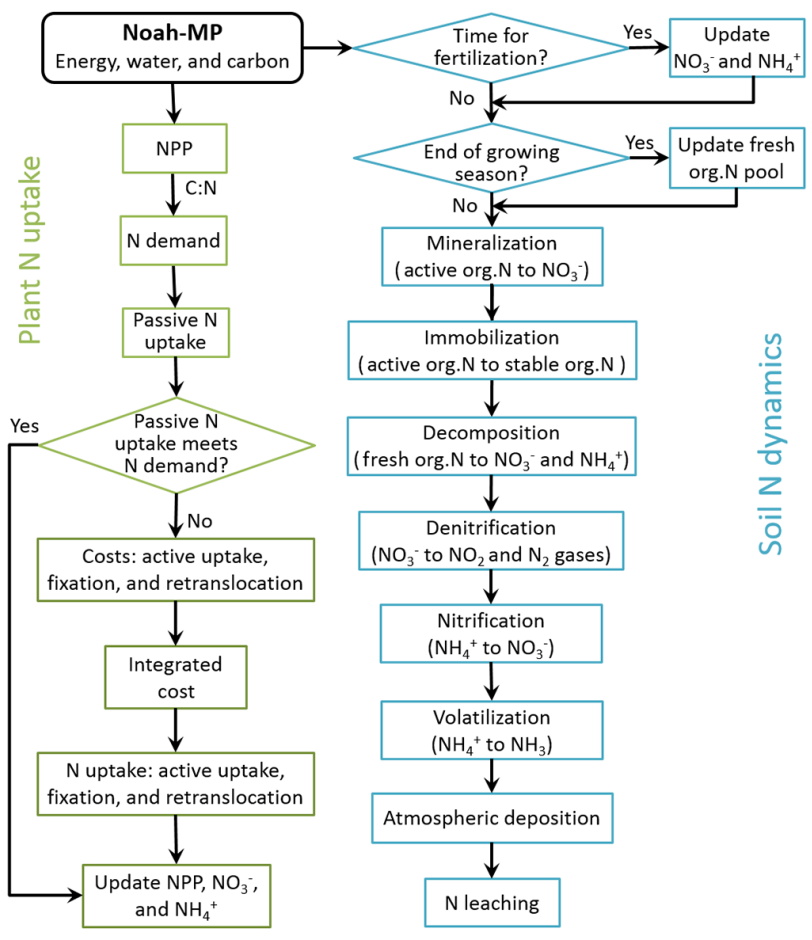

Figure 1. Flow chart of the nitrogen dynamic model. org.N: organic nitrogen.

ological $\mathrm{N}$ fixation; Eq. (5) active uptake; and Eq. (6), retranslocation (resorption).

Noah-MP calculates the NPP or its available carbon, $C_{\text {NPP }}\left(\mathrm{kg} \mathrm{C} \mathrm{m}^{-2}\right)$, following FUN. To maintain the prescribed carbon-to-nitrogen $(\mathrm{C}: \mathrm{N})$ ratio $\left(r_{\mathrm{C}: \mathrm{N}}\right)$, the $\mathrm{N}$ demand, $N_{\text {demand }}\left(\mathrm{kg} \mathrm{N} \mathrm{m}^{-2}\right)$, is calculated:

$N_{\text {demand }}=\frac{C_{\mathrm{NPP}}}{r_{\mathrm{C}: \mathrm{N}}}$,

where $r_{\mathrm{C}: \mathrm{N}}$ is the $\mathrm{C}: \mathrm{N}$ ratio for the whole plant, which is computed for each component (leaf, root, and wood) of the plant proportionally to the biomass. $\mathrm{C}: \mathrm{N}$ ratios for each component of the plant for each vegetation type are from Oleson et al. (2013).

Because no extra energetic cost is needed, passive uptake, $N_{\text {passive }}\left(\mathrm{kg} \mathrm{N} \mathrm{m}^{-2}\right)$, is the first and preferred source of $\mathrm{N}$ that a plant depletes:

$N_{\text {passive }}=N_{\text {soil }} \frac{E_{\mathrm{T}}}{s_{\mathrm{d}}}$,

where $N_{\text {soil }}$ is the available soil $\mathrm{N}$ for the given soil layer $\left(\mathrm{kg} \mathrm{N} \mathrm{m}^{-2}\right), E_{\mathrm{T}}$ is transpiration rate $\left(\mathrm{m} \mathrm{s}^{-1}\right)$, and $s_{\mathrm{d}}$ is the soil water depth (m). This pathway is typically a minor contributor except under very high soil $\mathrm{N}$ conditions.

If $N_{\text {passive }}$ is less than $N_{\text {demand }}$, then the remaining required $\mathrm{N}$ must be obtained from retranslocation $\left(N_{\text {resorb }}, \mathrm{kg} \mathrm{N} \mathrm{m}^{-2}\right)$, active uptake $\left(N_{\text {active }}, \mathrm{kg} \mathrm{N} \mathrm{m}^{-2}\right)$, or biological $\mathrm{N}$ fixation 
Table 1. Model input variables and parameters.

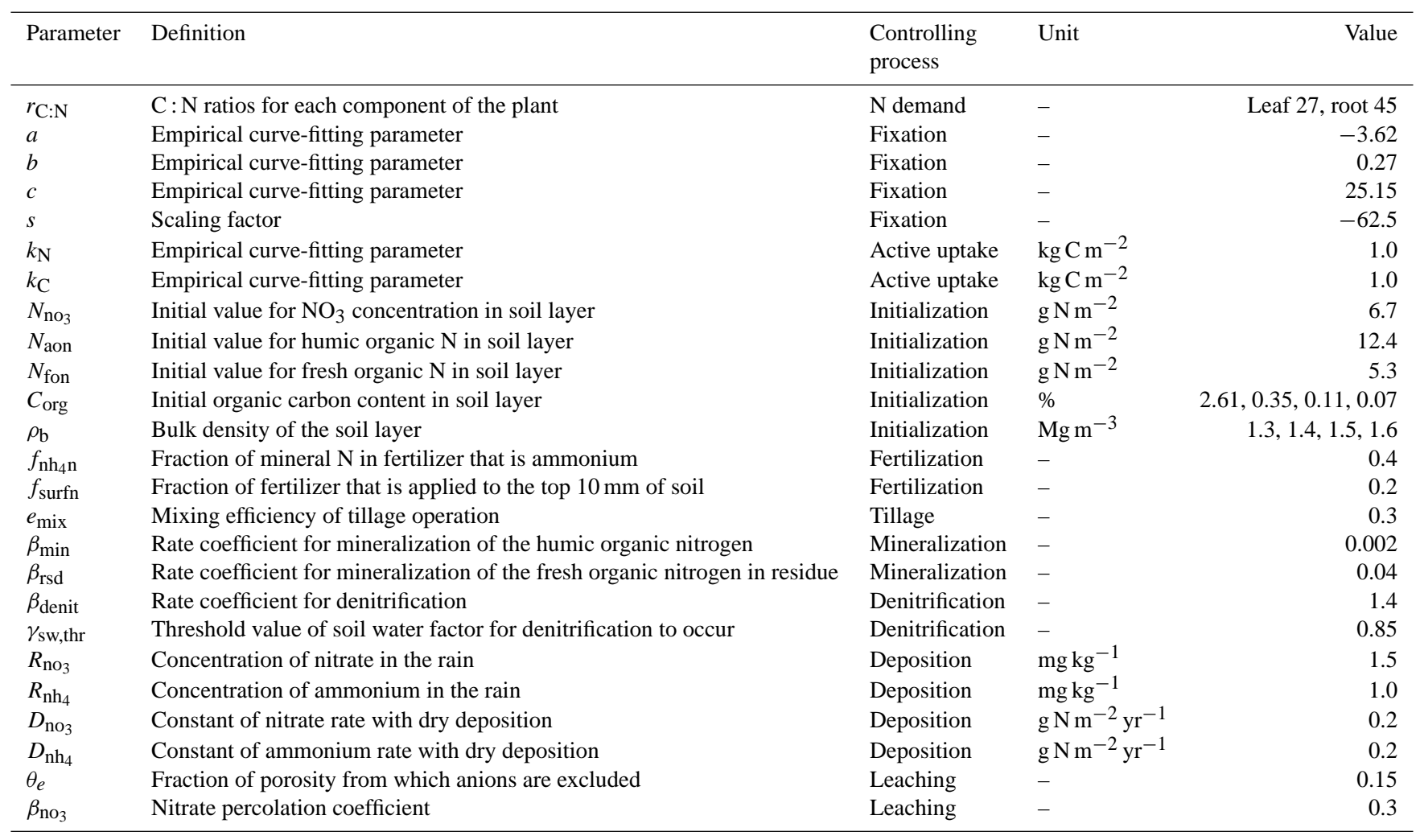

Note: some parameters are not described in the paper. The values for $C_{\mathrm{org}}$ and $\rho_{\mathrm{b}}$ are for the four soil layers.

$\left(N_{\mathrm{fix}}, \mathrm{kg} \mathrm{N} \mathrm{m}^{-2}\right)$, all of which are associated with energetic cost and hence require $\mathrm{C}$ expenditure $(\mathrm{C}$ cost). The $\mathrm{C}$ costs of fixation ( $\mathrm{Cost}_{\mathrm{fix}}, \mathrm{kg} \mathrm{C} \mathrm{kg} \mathrm{N}^{-1}$ ), active uptake (Costactive, $\mathrm{kgC} \mathrm{kg} \mathrm{N}^{-1}$ ), and resorption (Costresorb, $\mathrm{kg} \mathrm{C} \mathrm{kg} \mathrm{N}^{-1}$ ) are calculated as follows:

$$
\begin{aligned}
& \operatorname{Cost}_{\text {fix }}=s\left\{\exp \left[a+b \cdot T_{\text {soil }} \cdot\left(1-0.5 \cdot T_{\text {soil }} / c\right)\right]-2\right\}, \\
& \text { Cost }_{\text {active }}=\left(\frac{k_{\mathrm{N}}}{N_{\text {soil }}}\right)\left(\frac{k_{\mathrm{C}}}{C_{\text {root }}}\right), \\
& \text { Cost }_{\text {resorb }}=\frac{k_{R}}{N_{\text {leaf }}} .
\end{aligned}
$$

where $a, b$, and $c(-3.62,0.27$ and 25.15 , respectively) are empirical curve-fitting parameters (dimensionless) from Houlton et al. (2008); $s$ is a scaling factor $(=-62.5$; use $\mathrm{kg} \mathrm{C} \mathrm{kg} \mathrm{N}-1{ }^{\circ} \mathrm{C}$ for unit consistency); $T_{\text {soil }}$ is soil temperature $\left({ }^{\circ} \mathrm{C}\right) ; k_{\mathrm{N}}$ and $k_{\mathrm{C}}$ are both $1 \mathrm{~kg} \mathrm{C} \mathrm{m}^{-2} ; k_{R}$ is $0.01 \mathrm{~kg} \mathrm{C} \mathrm{m}^{-2}$; $C_{\text {root }}$ is total root biomass $\left(\mathrm{kg} \mathrm{C} \mathrm{m}^{-2}\right)$; and $N_{\text {leaf }}$ is the amount of $\mathrm{N}$ in the leaf $\left(\mathrm{kg} \mathrm{N} \mathrm{m}^{-2}\right)$. Active uptake is typically a dominant form of $\mathrm{N}$ uptake in natural ecosystems, consuming large quantities of NPP (that would otherwise go to growth or other allocations) in exchange for $\mathrm{N}$.

Similar to parallel circuits, each carbon cost is treated as a resistor, and the integrated cost $\left(\right.$ Cost $\left._{\mathrm{acq}}, \mathrm{kg} \mathrm{C} \mathrm{kg} \mathrm{N}^{-1}\right)$ is calculated (Brzostek et al., 2014):

$$
\frac{1}{\text { Cost }_{\mathrm{acq}}}=\frac{1}{\text { Cost }_{\mathrm{fix}}}+\frac{1}{\text { Cost }_{\text {resorb }}}+\sum_{i=1}^{n} \frac{1}{\text { Cost }_{\mathrm{active}, \mathrm{ly}}},
$$

where Costactive,ly is the $\mathrm{C}$ cost for active $\mathrm{N}$ uptake of soil layer ly and $n$ is the total number of soil layers.

Using Ohm's law, $\mathrm{N}$ acquired from $\mathrm{C}$ expenditure $\left(N_{\mathrm{acq}}\right.$, $\mathrm{kg} \mathrm{N} \mathrm{m}^{-2}$ ) is analogous to current and thus is calculated as follows:

$N_{\text {acq }}=\frac{C_{\text {acq }}}{\text { Cost }_{\text {acq }}}$.

Therefore, plant $\mathrm{N}$ uptake and fixation are computed and are updated for each $\mathrm{N}$ pool. In addition, the effect of $\mathrm{N}$ limitation on $\mathrm{CO}_{2}$ sequestration is represented in the model through the theory of $\mathrm{C}$ cost economics.

\subsubsection{Mineralization, decomposition, and immobilization}

Fresh organic residue is broken down into simpler organic components via decomposition. The plant-unavailable organic $\mathrm{N}$ is then converted into plant-available inorganic $\mathrm{N}$ via mineralization by microbes. Plant-available inorganic $\mathrm{N}$ can also be converted into plant-unavailable organic $\mathrm{N}$ via immobilization by microbes. 
Immobilization is incorporated into mineralization calculation (net mineralization). Mineralization and decomposition, which are only allowed to occur when soil temperature is above $0{ }^{\circ} \mathrm{C}$, are constrained by water availability and temperature. The nutrient-cycling temperature factor for soil layer ly, $\gamma_{\text {tmp,ly }}$, is calculated as follows:

$$
\begin{aligned}
\gamma_{\text {tmp,ly }} & = \\
0.9 & \cdot \frac{T_{\text {soil,ly }}}{T_{\text {soil l,ly }}+\exp \left[9.93-0.312 \cdot T_{\text {soil,ly }}\right]}+0.1,
\end{aligned}
$$

where $T_{\text {soil,ly }}$ is the temperature of soil layer ly $\left({ }^{\circ} \mathrm{C}\right)$.

The nutrient-cycling water factor for soil layer ly, $\gamma_{\mathrm{sw}, \mathrm{ly}}$, is calculated as follows:

$\gamma_{\mathrm{sw}, \mathrm{ly}}=\frac{\theta_{\mathrm{ly}}}{\theta_{\mathrm{s}, \mathrm{ly}}}$,

where $\theta_{\text {ly }}$ is the water content of soil layer ly $\left(\mathrm{mm} \mathrm{H}_{2} \mathrm{O}\right)$ and $\theta_{\mathrm{s}, \mathrm{ly}}$ is the water content of soil layer ly at field capacity $\left(\mathrm{mm} \mathrm{H}_{2} \mathrm{O}\right)$.

The mineralized $\mathrm{N}$ from the humus active organic $\mathrm{N}$ pool, $N_{\text {mina,ly }}\left(\mathrm{kg} \mathrm{N} \mathrm{m}^{-2}\right)$, is calculated as follows:

$N_{\text {mina,ly }}=\beta_{\text {mina,ly }}\left(\gamma_{\text {tmp,ly }} \cdot \gamma_{\text {sw,ly }}\right)^{1 / 2} \cdot N_{\text {aon,ly }}$,

where $\beta_{\text {mina }}$ is the rate coefficient for mineralization of the humus active organic nutrients and $N_{\text {aon,ly }}$ is the amount of $\mathrm{N}$ in the active organic pool $\left(\mathrm{kg} \mathrm{N} \mathrm{m}^{-2}\right)$.

The mineralized $\mathrm{N}$ from the residue fresh organic $\mathrm{N}$ pool, $N_{\text {minf,ly }}\left(\mathrm{kg} \mathrm{N} \mathrm{m}^{-2}\right)$, is calculated as follows:

$N_{\text {minf,ly }}=0.8 \cdot \delta_{\text {ntr,ly }} \cdot N_{\text {fon,ly }}$,

where $\delta_{\text {ntr,ly }}$ is the residue decay rate constant, and $N_{\text {fon,ly }}$ is the amount of $\mathrm{N}$ in the fresh organic pool $\left(\mathrm{kg} \mathrm{N} \mathrm{m}^{-2}\right)$.

The decomposed $\mathrm{N}$ from the residue fresh organic $\mathrm{N}$ pool, $N_{\text {dec,ly }}\left(\mathrm{kg} \mathrm{N} \mathrm{m}^{-2}\right)$, is calculated as follows:

$N_{\text {dec,ly }}=0.2 \cdot \delta_{\text {ntr,ly }} \cdot N_{\text {fon,ly }}$.

\subsubsection{Nitrification and ammonia volatilization}

Using a first-order kinetic rate equation, the total amount of ammonium lost to nitrification and volatilization in layer ly, $N_{\text {nit|vol,ly }}\left(\mathrm{kg} \mathrm{N} \mathrm{m}^{-2}\right)$, is calculated as follows:

$N_{\text {nit|vol,ly }}=\mathrm{NH}_{4, \text { ly }} \cdot\left[1-\exp \left(-\eta_{\text {nit,ly }}-\eta_{\text {vol,ly }}\right)\right]$,

where $\mathrm{NH}_{4, \text { ly }}$ is the amount of ammonium in layer ly $\left(\mathrm{kg} \mathrm{N} \mathrm{m}^{-2}\right), \eta_{\text {nit,ly }}$ is the nitrification regulator, and $\eta_{\mathrm{vol}, \mathrm{ly}}$ is the volatilization regulator. The calculation of $\eta_{\text {nit,ly }}$ and $\eta_{\mathrm{vol}, \text { ly }}$ is described in Neitsch et al. (2011).

$N_{\text {nit|vol,ly }}$ is then partitioned to nitrification and volatilization. The amounts of $\mathrm{N}$ converted from $\mathrm{NH}_{4}^{+}$and $\mathrm{NO}_{3}^{-}$of the ammonium pool via nitrification and volatilization are then calculated:

$N_{\text {nit,ly }}=\frac{\mathrm{fr}_{\text {nit,ly }}}{\left(\mathrm{fr}_{\text {nit,ly }}+\mathrm{fr}_{\mathrm{vol}, \mathrm{ly}}\right)} \cdot N_{\text {nit|vol,ly }}$,
$N_{\text {vol,ly }}=\frac{\mathrm{fr}_{\mathrm{vol}, \mathrm{ly}}}{\left(\mathrm{fr}_{\text {nit,ly }}+\mathrm{fr}_{\mathrm{vol}, \text { ly }}\right)} \cdot N_{\text {nit|vol,ly }}$,

where $\mathrm{fr}_{\text {nit,ly }}$ and $\mathrm{fr}_{\text {nit,ly }}$ are the estimated fractions of $\mathrm{N}$ lost through nitrification and volatilization, respectively. They are calculated from the individual regulator in Eq. (14) as follows:

$\mathrm{fr}_{\text {nit,ly }}=1-\exp \left[-\eta_{\text {nit,ly }}\right]$,

$\mathrm{fr}_{\mathrm{vol}, \mathrm{ly}}=1-\exp \left[-\eta_{\mathrm{vol}, \mathrm{ly}}\right]$.

\subsubsection{Denitrification}

Denitrification is the process of bacteria removing $\mathrm{N}$ from soil (converting $\mathrm{NO}_{3}^{-}$to $\mathrm{N}_{2}$ or $\mathrm{N}_{2} \mathrm{O}$ gases). Denitrification rate, $N_{\text {denit,ly }}\left(\mathrm{kg} \mathrm{N} \mathrm{m}^{-2}\right)$, is calculated as follows:

$\left\{\begin{array}{cc}N_{\text {denit,ly }}= & \mathrm{NO}_{3, \text { ly }} \cdot\left[1-\exp \left(-\beta_{\text {denit }} \cdot \gamma_{\text {tmp,ly }}\right.\right. \\ & \left.\left.\cdot \operatorname{orgC}_{\text {ly }}\right)\right] \text { if } \gamma_{\mathrm{sw}, l y} \geq \gamma_{\mathrm{sw}, \text { thr }} \\ N_{\text {denit,ly }}=0 & \text { if } \gamma_{\mathrm{sw}, \text { ly }} \geq \gamma_{\mathrm{sw}, \mathrm{thr}}\end{array}\right.$,

where org $\mathrm{C}_{\mathrm{ly}}$ is the amount of organic $\mathrm{C}$ in the layer (\%), $\beta_{\text {denit }}$ is the rate coefficient for denitrification, and $\gamma_{\mathrm{sw}, \text { thr }}$ is the threshold value of $\gamma_{\mathrm{sw}, \mathrm{ly}}$ for denitrification to occur.

\subsubsection{Atmospheric deposition}

While the mechanism of atmospheric deposition is not fully understood, the uncertainty is parameterized into the concentration of nitrate/ammonium in the rain for wet deposition, and the nitrate/ammonium deposition rate for dry deposition.

The amounts of nitrate and ammonium added to the soil through wet deposition, $\mathrm{NO}_{3}$, wet $\left(\mathrm{kg} \mathrm{N} \mathrm{m}^{-2}\right)$ and $\mathrm{NH}_{4}$, wet $\left(\mathrm{kg} \mathrm{N} \mathrm{m}^{-2}\right)$, are calculated as follows:

$\mathrm{NO}_{3, \text { wet }}=0.01 \cdot R_{\mathrm{NO}_{3}} \cdot P$,

$\mathrm{NH}_{4, \text { wet }}=0.01 \cdot R_{\mathrm{NH}_{4}} \cdot P$,

where $R_{\mathrm{NO}_{3}}$ is the concentration of nitrate in the rain $\left(\mathrm{mg} \mathrm{N} \mathrm{L}^{-1}\right), R_{\mathrm{NH}_{4}}$ is the concentration of ammonium in the rain $\left(\mathrm{mg} \mathrm{N}^{-1}\right)$, and $P$ is the amount of precipitation. The values for $R_{\mathrm{NO}_{3}}$ and $R_{\mathrm{NH}_{4}}$ used in this study are listed in Table 1.

\subsubsection{Fertilizer application}

The $\mathrm{N}$ fertilizer application process is included in the new model as well. If real fertilizer application data (timing and amount for a specific year) are available, they can be used as model inputs. Otherwise, a fixed amount of $\mathrm{N}$ fertilizer (e.g., $7.8 \mathrm{~g} \mathrm{~N} \mathrm{~m}^{-2} \mathrm{yr}^{-1}$ in this study) is applied at a fixed time of a year (e.g., 20 June in this study). 


\subsubsection{Leaching}

$\mathrm{N}$ leaching from land to water bodies is a consequence of soil weathering and erosion processes. In particular, organic $\mathrm{N}$ attached to soil particles is transported to surface water through soil erosion. Therefore, the modified universal soil loss equation (USLE) (Williams, 1995) is used to determine soil erosion. The details of the calculation are described in Neitsch et al. (2011).

$\mathrm{N}$ in nitrate form can be transported with surface runoff, lateral runoff, or percolation, which is calculated as follows:

$$
\begin{aligned}
& \mathrm{NO}_{3, \text { surf }}=\beta_{\mathrm{NO}_{3}} \cdot \operatorname{conc}_{\mathrm{NO}_{3}} \text {, mobile } \cdot Q_{\text {surf }} \text {, }
\end{aligned}
$$

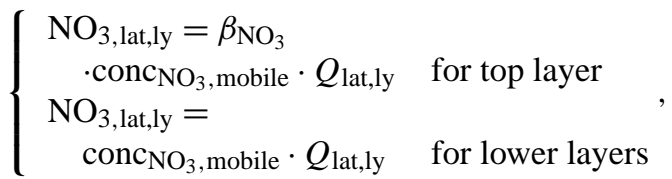

$$
\begin{aligned}
& \mathrm{NO}_{3, \text { perc }}=\text { conc }_{\mathrm{NO}_{3}} \text {, mobile } \cdot w_{\text {perc,ly }} \text {, }
\end{aligned}
$$

where $\mathrm{NO}_{3 \text {,surf }}, \mathrm{NO}_{3, \text { lat,ly }}$, and $\mathrm{NO}_{3 \text {,perc }}$ are the soil nitrates removed in surface runoff, in subsurface flow, and by percolation, respectively $\left(\mathrm{kg} \mathrm{N} \mathrm{m}^{-2}\right) ; \beta_{\mathrm{NO}_{3}}$ is the nitrate perco-

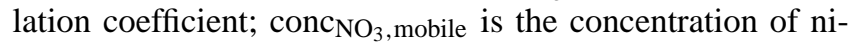
trate in the mobile water in the layer $\left(\mathrm{kg} \mathrm{N} \mathrm{mm} \mathrm{H}_{2} \mathrm{O}^{-1}\right)$, and $w_{\text {perc,ly }}$ is the amount of water percolating to the underlying soil layer $\left(\mathrm{mm} \mathrm{H}_{2} \mathrm{O}\right), Q_{\text {surf }}$ is the generated surface runoff $\left(\mathrm{mm} \mathrm{H}_{2} \mathrm{O}\right)$, and $Q_{\text {lat,ly }}$ is the water discharged from the layer by lateral flow $\left(\mathrm{mm} \mathrm{H}_{2} \mathrm{O}\right)$.

\subsection{Description of evaluation data and model configuration}

At the regional scale, N-related measurements are very limited. Even at site level, measurements are limited with respect to plant and carbon dynamics. The Kellogg Biological Station (KBS) - a Long Term Ecological Research (LTER) site - is unique in its long-term continuous measurements of $\mathrm{N}$ related variables (soil nitrate, $\mathrm{N}$ leaching, mineralization, nitrification, and fertilizer application) in an agricultural setting with multiple crop and soil controls. Even within the LTER Network, we cannot find a second site that conducts this integrated suite of measurements. Therefore, the new model is evaluated at this site.

KBS is located in Hickory Corners, Michigan, USA, within the northeastern portion of the US Corn Belt $\left(42.40^{\circ} \mathrm{N}, 85.40^{\circ} \mathrm{W}\right.$, elevation $\left.288 \mathrm{~m}\right)$. Mean annual temperature is $10.1{ }^{\circ} \mathrm{C}$, and mean annual precipitation is $1005 \mathrm{~mm}$, with about half falling as snow. This study uses two treatments from this site: $\mathrm{T} 1$ cropland with conventional tillage and $\mathrm{T} 2$ cropland without tillage. Both treatments are rainfed and are planted with the same crops: corn, soybean, and winter wheat in rotation.

This site features multiple N-related measurements. Soil inorganic $\mathrm{N}$ concentration, which is sampled from the surface to $25 \mathrm{~cm}$ soil depth, is available from 1989 to 2012 . Concentration of inorganic $\mathrm{N}$ leaching at bedrock, which is sampled at $1.2 \mathrm{~m}$ of soil depth, is available from 1995 to 2013 . These two measurements are used to evaluate model-simulated concentrations of soil nitrate for the top $25 \mathrm{~cm}$ and nitrate leaching from the soil bottom. Soil N mineralization, which measures the net mineralization potential and is available from 1989 to 2012 , is compared with the modeled mineralization rate qualitatively.

In addition, soil moisture content is sampled from the surface to $25 \mathrm{~cm}$ soil depth and is calculated on a dry-weight basis. In order to compare with model output, it is converted to volumetric soil moisture by applying the soil bulk density. Annual NPP is converted from annual crop yields (19892013) by assuming a harvest index and a root-to-whole-plant ratio for each crop type. The harvest indices for corn, soybean, and winter wheat are $0.53,0.42$, and 0.39 , respectively. The root-to-shoot ratios for corn, soybean, and winter wheat are $0.18,0.15$, and 0.20 , respectively (Prince et al., 2001; West et al., 2010). Although $\mathrm{N}$ uptake cannot be evaluated directly at this site, by evaluating the annual NPP, we can see the model's performance in representing the $\mathrm{N}$ limitation effect on plant growth.

Noah-MP requires the following atmospheric forcing data at least at a 3-hourly time step: precipitation, air temperature, specific humidity, surface air pressure, wind speed, incoming solar radiation, and incoming longwave radiation. The weather station at the site measures all of these except for incoming longwave radiation, but it does not cover the entire period from 1989 to 2014 (e.g., hourly precipitation data are only available since 2007), when the $\mathrm{N}$ data are available. Therefore, atmospheric forcing data are extracted from the $0.125^{\circ} \times 0.125^{\circ}$ gridded forcing data from the North American Land Data Assimilation System (NLDAS; Xia et al., 2012). Table 2 compares the atmospheric forcing data between NLDAS and site measurements for 2008-2014. We can see that the differences in precipitation and air temperature - the two most important forcing fields for $\mathrm{N}$ cycling are very small, with relative biases -1.4 and $4.2 \%$, respectively.

Finally, the site management log records the detailed operational practices such as soil preparation, planting, fertilizer application, pesticide application, and harvest. $\mathrm{N}$ fertilizer application data include the date of application, rate, fertilizer type, and equipment used. The fertilizer application date and rate are used as model inputs.

\section{Results and analyses}

\subsection{Evaluation of soil moisture}

Modeled volumetric soil moisture, which is important for nutrient cycling and plant growth, is compared to measured soil moisture (Fig. 2). The model performs reasonably well on both treatments (i.e., with and without tillage) in terms of capturing the mean and seasonal variation, which is consis- 
Table 2. Comparison of annual averaged atmospheric forcing data (2008-2014) between site observation and NLDAS.

\begin{tabular}{lrrrrrrr}
\hline Source & $\begin{array}{r}\text { Precipitation } \\
(\mathrm{mm})\end{array}$ & $\begin{array}{r}\text { Air } \\
\text { temperature } \\
\left({ }^{\circ} \mathrm{C}\right)\end{array}$ & $\begin{array}{r}\text { Relative } \\
\text { humidity } \\
(\%)\end{array}$ & $\begin{array}{r}\text { Pressure } \\
(\mathrm{hPa})\end{array}$ & $\begin{array}{r}\text { Shortwave } \\
\text { radiation } \\
\left(\mathrm{W} \mathrm{m}^{-2}\right)\end{array}$ & $\begin{array}{r}\text { Wind } \\
\text { speed } \\
\left(\mathrm{m} \mathrm{s}^{-1}\right)\end{array}$ & $\begin{array}{r}\text { Wind } \\
\text { direction } \\
\left({ }^{\circ}\right)\end{array}$ \\
\hline Site obs. & 937.19 & 9.15 & 73.44 & 982.29 & 157.07 & 3.37 & 194.72 \\
NLDAS & 924.45 & 9.55 & 76.50 & 983.47 & 171.03 & 4.74 & 206.43 \\
\hline
\end{tabular}
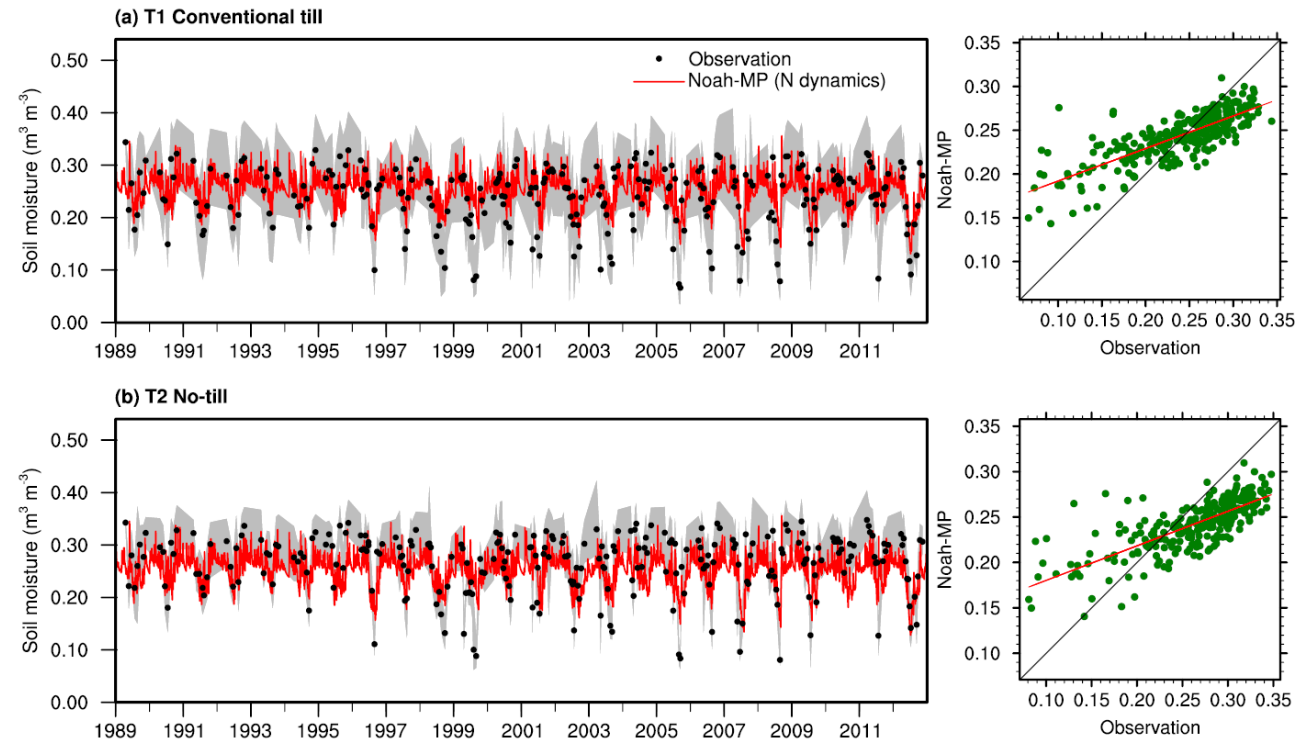

Figure 2. Observed and model-simulated volumetric soil moisture from 1989 to 2012 for (a) treatment 1 - cropland with conventional tillage - and (b) treatment 2: cropland without tillage. The grey shaded area shows the observational ranges from up to six replicates for each treatment.

tent with previous study by Cai et al. (2014b). The modelsimulated multiple year averages are both 0.243 for the two treatments. These are very close to observations, which are 0.238 and 0.264 for $\mathrm{T} 1$ and $\mathrm{T} 2$, respectively. The correlation coefficient is 0.78 for $\mathrm{T} 1$ and 0.76 for $\mathrm{T} 2$, which are considered high skills, especially on a daily scale.

However, differences between modeled and observed soil moisture are also found. From observation (Fig. 2), we can see that the treatment without tillage (T2) has slightly higher soil moisture than the treatment with tillage (T1). Therefore, tillage practice reduces soil moisture. However, the difference in modeled soil moisture is negligible between the two treatments (both are 0.243). This is because Noah-MP does not consider water redistribution due to tillage, although $\mathrm{N}$ redistribution is considered in the soil $\mathrm{N}$ dynamic sub-model. $\mathrm{N}$ is redistributed by mixing a certain depth (i.e., $100 \mathrm{~mm}$ ) of soil with a mixing efficiency (i.e., $30 \%$ ) (Neitsch et al., 2011). In addition, observed soil moisture has higher variations. As we can see from Fig. 2, observation tends to have either higher peaks or lower valleys than model simulation. We also notice that some values from observation are extremely low, which may not be necessarily true in reality. Consider- ing the wide spread of the observational ranges defined by up to six replicating plots, Noah-MP provides a reasonable water environment for the $\mathrm{N}$ cycling.

\subsection{Evaluation of soil nitrate}

Soil nitrate concentration is the outcome of all N-related processes that occur in soil such as decomposition, mineralization, nitrification, denitrification, and uptake. It determines the available $\mathrm{N}$ that plants can use. The skills in modeling the soil nitrate concentration reflect the overall performance of the model in simulating the $\mathrm{N}$ cycle. Figure 3 shows the comparison of the model-simulated soil nitrate concentration with site observations for both $\mathrm{T} 1$ and $\mathrm{T} 2$. The model captures the major variations of the soil nitrate. $\mathrm{N}$ fertilizer application is responsible for the high peaks. These high peaks drop very fast at first and then drop slowly, which can sustain crop growth for a few months.

The multi-year average of modeled soil nitrate concentration is $5.77 \mathrm{mg} \mathrm{kg}^{-1}$ ( $4.90 \mathrm{mg} \mathrm{kg}^{-1}$ ) for $\mathrm{T} 1$ (T2), which is consistent with the observed $5.61 \mathrm{mg} \mathrm{kg}^{-1}\left(4.81 \mathrm{mg} \mathrm{kg}^{-1}\right)$. Correlation coefficients are 0.58 and 0.56 for $\mathrm{T} 1$ for $\mathrm{T} 2$, respectively. From the wide spread of the range error bars, we 

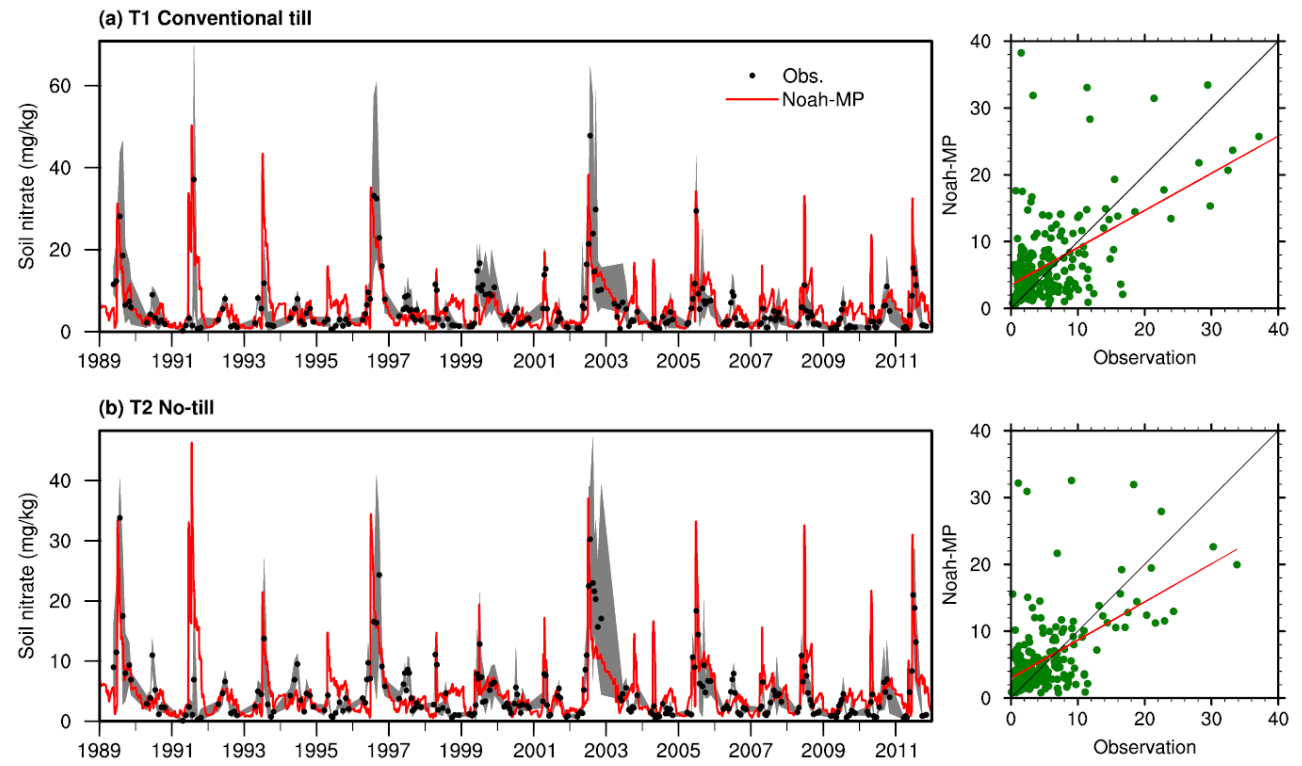

Figure 3. Observed and model-simulated soil nitrate concentration from 1989 to 2011 for (a) treatment 1 - cropland with conventional tillage - and (b) treatment 2: cropland without tillage. The grey shaded area shows the observational ranges from up to six replicates for each treatment.

Table 3. Annual averages of Noah-MP-simulated major nitrogen fluxes and NPP. The NPP within the parentheses is from observation.

\begin{tabular}{|c|c|c|c|c|c|c|c|c|c|}
\hline \multirow[t]{2}{*}{ Treatment } & \multirow{2}{*}{$\begin{array}{r}\mathrm{NPP} \\
\left(\mathrm{gC} \mathrm{m}^{-2}\right)\end{array}$} & \multicolumn{4}{|c|}{ Uptake } & \multirow{2}{*}{$\begin{array}{r}\text { Humus } \\
\text { mineralization } \\
\left(\mathrm{gN} \mathrm{m}^{-2}\right)\end{array}$} & \multirow{2}{*}{$\begin{array}{r}\text { Residue } \\
\text { decomposition } \\
\left(\mathrm{gN} \mathrm{m}^{-2}\right)\end{array}$} & \multirow{2}{*}{$\begin{array}{l}\text { Denitrification } \\
\qquad\left(\mathrm{gN} \mathrm{m}^{-2}\right)\end{array}$} & \multirow{2}{*}{$\begin{array}{r}\text { Leaching } \\
\left(\mathrm{gN} \mathrm{m}^{-2}\right)\end{array}$} \\
\hline & & $\begin{array}{r}\text { Passive } \\
\left(\mathrm{gN} \mathrm{m}^{-2}\right)\end{array}$ & $\begin{array}{r}\text { Active } \\
\left(\mathrm{gN} \mathrm{m}^{-2}\right)\end{array}$ & $\begin{array}{r}\text { Fixation } \\
\left(\mathrm{gN} \mathrm{m}^{-2}\right)\end{array}$ & $\begin{array}{l}\text { Retranslocation } \\
\qquad\left(\mathrm{gN} \mathrm{m}^{-2}\right)\end{array}$ & & & & \\
\hline $\mathrm{T} 1$ & $432(437)$ & 6.18 & 0.90 & 2.88 & 0.50 & 3.79 & 12.30 & 10.48 & 7.19 \\
\hline $\mathrm{T} 2$ & $441(471)$ & 6.62 & 0.69 & 2.84 & 0.50 & 2.64 & 9.34 & 8.80 & 4.77 \\
\hline
\end{tabular}

can see that soil $\mathrm{N}$ dynamics may be affected by a variety of complicated factors, which makes it difficult to model. Therefore, although the correlation coefficients are not considered high skills relative to the soil moisture statistics, they are still reasonable.

While both treatments show very similar patterns (Fig. 3), T1 with conventional tillage tends to have higher soil nitrate concentration. This is understandable because tillage practices redistribute water and nutrients in soil, which accelerates the $\mathrm{N}$ cycling. Table 3 shows annual averages of major $\mathrm{N}$ fluxes for both treatments. T1 has higher rates of humus mineralization and residue decomposition, but, at the same time, it also has higher rates of denitrification and leaching. Therefore, it produces more $\mathrm{N}_{2} \mathrm{O}$ (a greenhouse gas) and more $\mathrm{N}$ runoff to rivers. Particularly, with higher $\mathrm{N}$ leaching, less soil nitrate is available for passive uptake by plants. As a result, plants need to acquire more $\mathrm{N}$ through active uptake.

\subsection{Evaluation of nitrate leaching from soil bottom}

$\mathrm{N}$ leaching can be transported to rivers through surface and subsurface runoff and to groundwater through percolation from soil bottom. Only the last pathway is measured at this site. Figure 4 shows the comparison of concentrations of the leached solution from the soil bottom between model simulation and observation. The averaged concentration of $\mathrm{N}$ leaching from the soil bottom for $\mathrm{T} 1$ (T2) is $12.84 \mathrm{mg} \mathrm{kg}^{-1}\left(8.86 \mathrm{mg} \mathrm{kg}^{-1}\right)$ from model simulation and $13.57 \mathrm{mg} \mathrm{kg}^{-1}\left(9.26 \mathrm{mg} \mathrm{kg}^{-1}\right)$ from observation. The correlation coefficients are 0.43 and 0.40 for $\mathrm{T} 1$ and $\mathrm{T} 2$, respectively. Although these skills may not be considered satisfactory, the model can still produce comparable results with observation.

The peak in 2003 is extremely high and long lasting. This is probably due to the abnormal pattern of precipitation distribution in 2003. In a normal year, storms higher than $50 \mathrm{~mm}$ usually occur in either summer or fall. However, in 2003, there was an early storm on 4 April which reached $61 \mathrm{~mm}$ in 1 day. As we can see from Fig. 3, the soil nitrate concentra- 
(a) T1 Conventional till

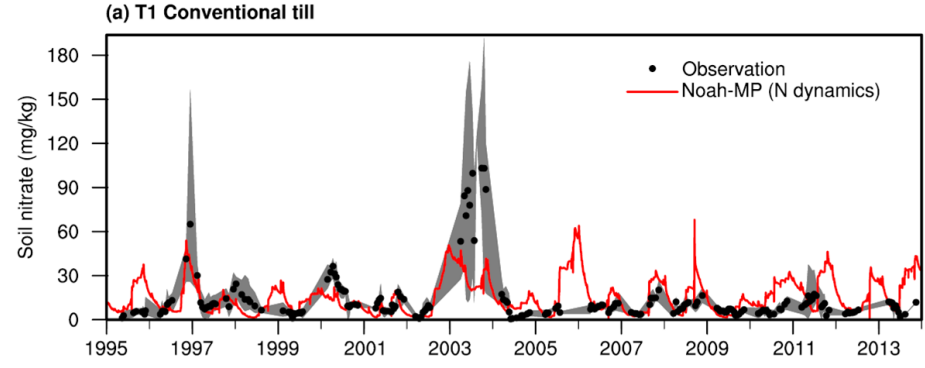

(b) T2 No-till

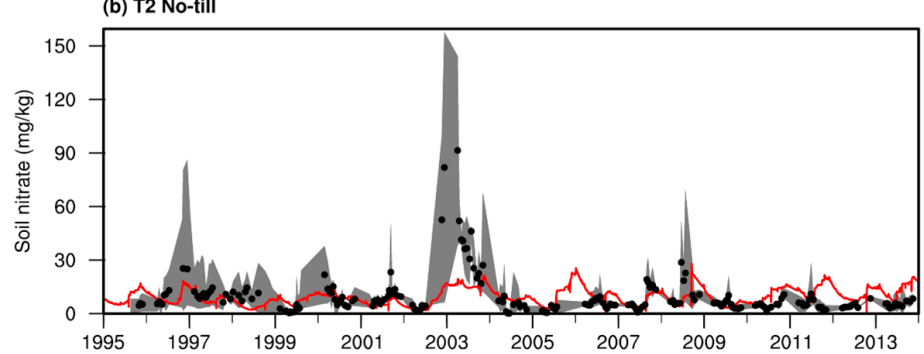

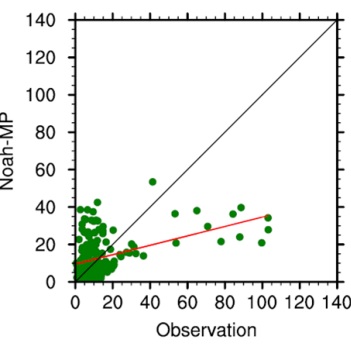

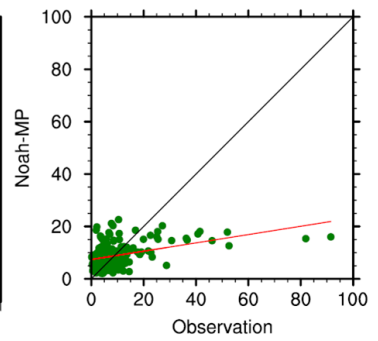

Figure 4. Observed and model-simulated nitrate leaching from bottom of soil profile from 1995 to 2013 for (a) treatment 1 - cropland with conventional tillage - and (b) treatment 2: cropland without tillage. The grey shaded area shows the observational ranges from up to six replicates for each treatment.

tion is also high. The combination of high water infiltration (due to the storm) and high soil nitrate concentration resulted in a large amount of soil nitrate being brought to the bottom soil layer. A few months following that, there was no large storm, which was again different from a normal year. As a result, the high-concentration nitrate solution was drained slowly out of the bottom layer of soil. The modeled nitrate leaching also shows a peak over this period, but the values are only close to the lower bound of the observed range. This suggests that improvement is needed so the model can better capture peaks under this situation.

We also notice that, without tillage, $\mathrm{N}$ leaching is about one-third lower than that with tillage. Without tillage, the temporal variation is also smaller.

\subsection{Evaluation of annual NPP}

NPP indicates the amount of $\mathrm{C}$ that is assimilated from the atmosphere into plants and thus is important in studying not only crop and ecosystem productivity but also climate change feedbacks. NPP is mainly determined by plant photosynthesis and autotrophic respiration. It is also affected by water and nutrient stresses. In this study, $\mathrm{N}$ stress on plant growth is calculated by the reduction of NPP due to N acquisition, which can be considered another form of plant respiration. Figure 5 shows the comparison of simulated annual NPP against observation. Since the original Noah-MP without $\mathrm{N}$ dynamics also simulates NPP, its results are also shown here as a reference. The mean annual NPP simulated by the original Noah-MP is $544 \mathrm{gC} \mathrm{m}^{-2}$ (the same simulation for both treatments as original Noah-MP does not distinguish tillage and no tillage). By including the $\mathrm{N}$ dynamics, simulated annual NPP is reduced to $432 \mathrm{gC} \mathrm{m}^{-2}\left(441 \mathrm{gC} \mathrm{m}^{-2}\right)$ for $\mathrm{T} 1$ (T2), which is more consistent with observed $437 \mathrm{gC} \mathrm{m}^{-2}$ $\left(471 \mathrm{gC} \mathrm{m}^{-2}\right)$. The correlation coefficient increased to 0.77 for $\mathrm{T} 1$, and from 0.30 to 0.72 for $\mathrm{T} 2$, which is a significant improvement. This improvement is due to the better characterization of the amount of carbon allocated to $\mathrm{N}$ acquisition instead of growth.

The modeled rate of NPP down-regulation - the fraction of NPP reduction due to N limitation - is 35.4 and $34.7 \%$ for $\mathrm{T} 1$ and $\mathrm{T} 2$, respectively. These rates are close to the $33 \%$ of down-regulation rate used in the default Noah-MP. By dynamically simulating the demand and supply of $\mathrm{N}$ with time, these become even closer to the observations.

Surprisingly, even with slower N cycling, T2 produces slightly higher NPP (Table 3), which is consistent between model and observation. If this is the case, except for drying up soil, releasing more $\mathrm{N}_{2} \mathrm{O}$ gas, and producing more $\mathrm{N}$ leaching, is there any benefit from tillage? The answer is yes. Less $\mathrm{N}$ fertilizer is needed for cropland with tillage. Based on the site management $\log$, in total there was $194.8 \mathrm{gN} \mathrm{m}^{-2}$ of $\mathrm{N}$ fertilizer applied to T1 from 1989 to 2013, which is less than the amount $\left(210.7 \mathrm{gN} \mathrm{m}^{-2}\right)$ applied to $\mathrm{T} 2$ during the same period.

\subsection{Impacts of nitrogen dynamics on carbon cycle}

The coupling of the $\mathrm{N}$ dynamics into Noah-MP not only adds N-related modeling but also affects other components of the model, i.e., the carbon and water cycles. This is because the change in NPP affects leaf biomass and hence LAI. 
(a) T1 Conventional till

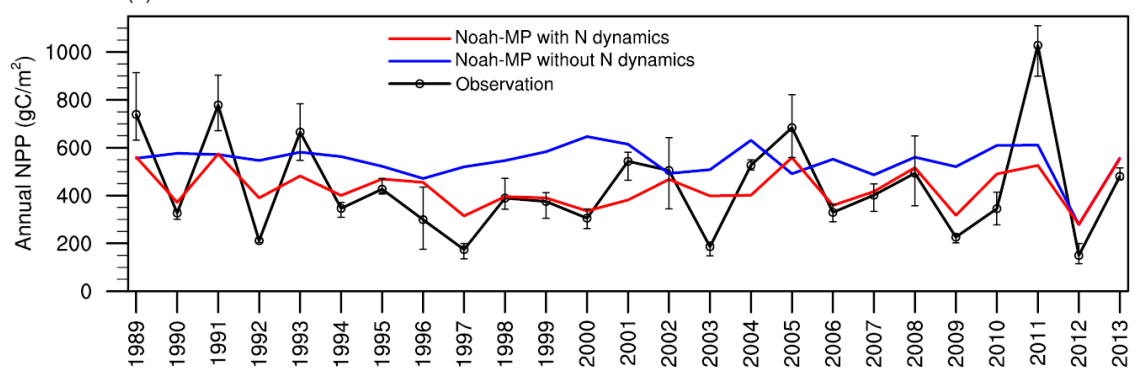

(b) T2 No-till

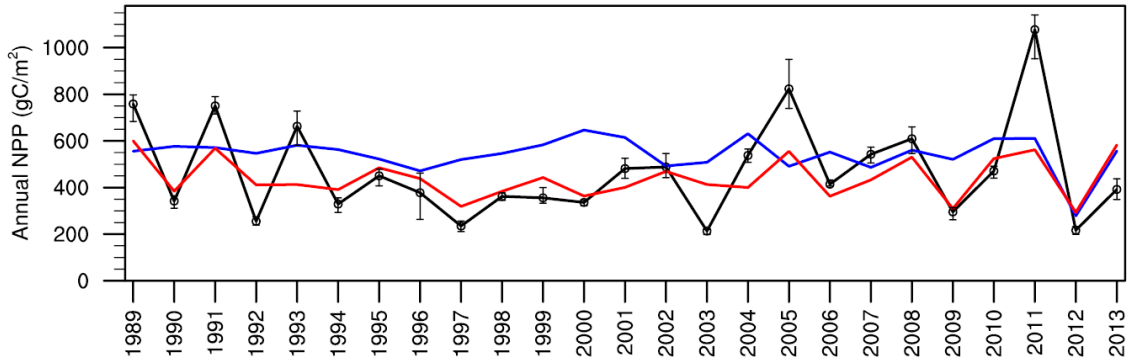

Figure 5. Observed and modeled annual NPP from 1989 to 2013 for (a) treatment 1 - cropland with conventional tillage - and (b) treatment 2: cropland without tillage. The error bars show the observational ranges from up to six replicates for each treatment.

The change in LAI can affect photosynthesis, which in return affects NPP.

Figure 6 shows the comparison of the simulated C-related state and flux variables between the default and $\mathrm{N}$ dynamics enhanced Noah-MP. We can see that NPP is decreased from 544 to $432 \mathrm{gC} \mathrm{m}^{-2}$. Most of the decrease occurs before the peak growing season, which results in a slight decrease in LAI. However, the peak LAI has very minor increase. After the peak, LAI decreases more slowly than the default, which is due to the decreased turnover rate proportional to the NPP down-regulation rate. If the turnover rate is not down-regulated accordingly, the peak LAI will be cut in half. Due to the slower turnover rate, more leaf biomass (indicated by LAI) is involved in photosynthesis. Therefore, compared to the default, Noah-MP with $\mathrm{N}$ dynamics generates higher gross primary production (GPP) during the second half of the growing season, although it is lower during the first half of the growing season. Annual mean GPP is decreased by about $28 \mathrm{gC} \mathrm{m}^{-2}$.

Net ecosystem exchange (NEE) has a similar change. The annual NEE is $-179 \mathrm{gC} \mathrm{m}^{-2}\left(-183 \mathrm{gC} \mathrm{m}^{-2}\right)$ from Noah-MP with $\mathrm{N}$ dynamics (default Noah-MP), which is comparable to the NEE in West et al. (2010) for this region. Its absolute value is decreased by $4 \mathrm{gC} \mathrm{m}^{-2}$, which means that the $\mathrm{C}$ sink is slightly decreased. This decrease is small compared to the GPP decrease, probably because soil respiration is also decreased. All annual peaks of NPP, LAI, GPP, and NEE are delayed for about half a month. This is probably due to the fact that the primary $\mathrm{N}$ fertilizations $\left(>10 \mathrm{gN} \mathrm{m}^{-2}\right)$ were mainly applied after late June and thus plants encountered high $\mathrm{N}$ stress during the first half of the growing season.

\subsection{Impacts of nitrogen dynamics on water cycle}

Through the changes in LAI and soil organic matters (SOMs), the addition of $\mathrm{N}$ dynamics affects not only the carbon cycle but also the water cycle. The change in SOM is not currently considered, and therefore the impacts on the water cycle are from the change in LAI only, as shown in Fig. 7. These impacts are most pronounced on plant transpiration, which is increased by $33 \mathrm{~mm} \mathrm{yr}^{-1}$. The increase mostly occurs during and after the peak growing season. In Cai et al. (2014a), Noah-MP-simulated evapotranspiration (ET) over croplands increases too fast during the first half of the growing season and reaches peak about 1 month earlier than observation. The delayed peaks of LAI and ET can partly mitigate this issue. As there is more water extracted from soil by transpiration, soil moisture further decreases during the second half of the growing season. Therefore, less water is available and thus soil evaporation is decreased by $9 \mathrm{~mm} \mathrm{yr}^{-1}$. With the increase in ET, runoff is decreased by $13 \mathrm{~mm} \mathrm{yr}^{-1}$.

Therefore, besides the great implications for $\mathrm{C}$ modeling and the potential for being used in environmental predictions, the addition of $\mathrm{N}$ dynamics can improve the hydrological simulations as well. 
(a) NPP
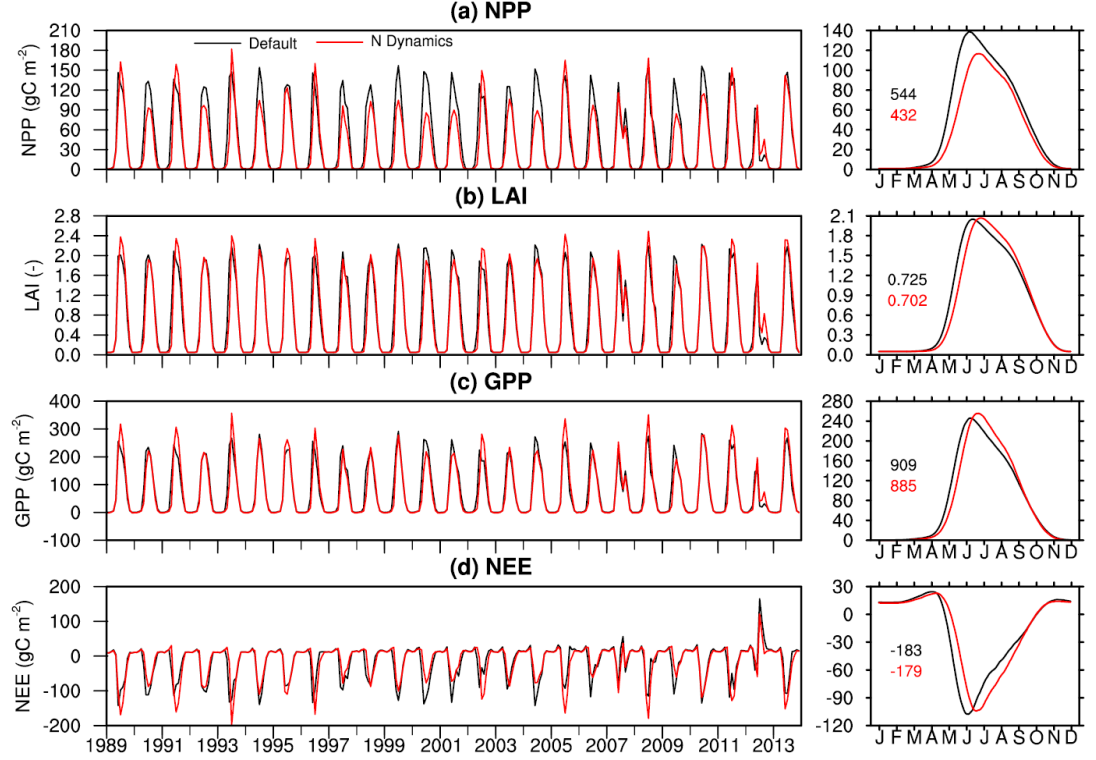

Figure 6. (left column) Monthly and (right column) climatologically seasonal cycle of model-simulated (a) LAI, (b) NPP, (c) GPP, and (d) NEE from default Noah-MP and enhanced Noah-MP with $\mathrm{N}$ dynamics. The values in the right column indicate annual mean for each term (black: Noah-MP without $\mathrm{N}$ dynamics; red: Noah-MP with $\mathrm{N}$ dynamics).
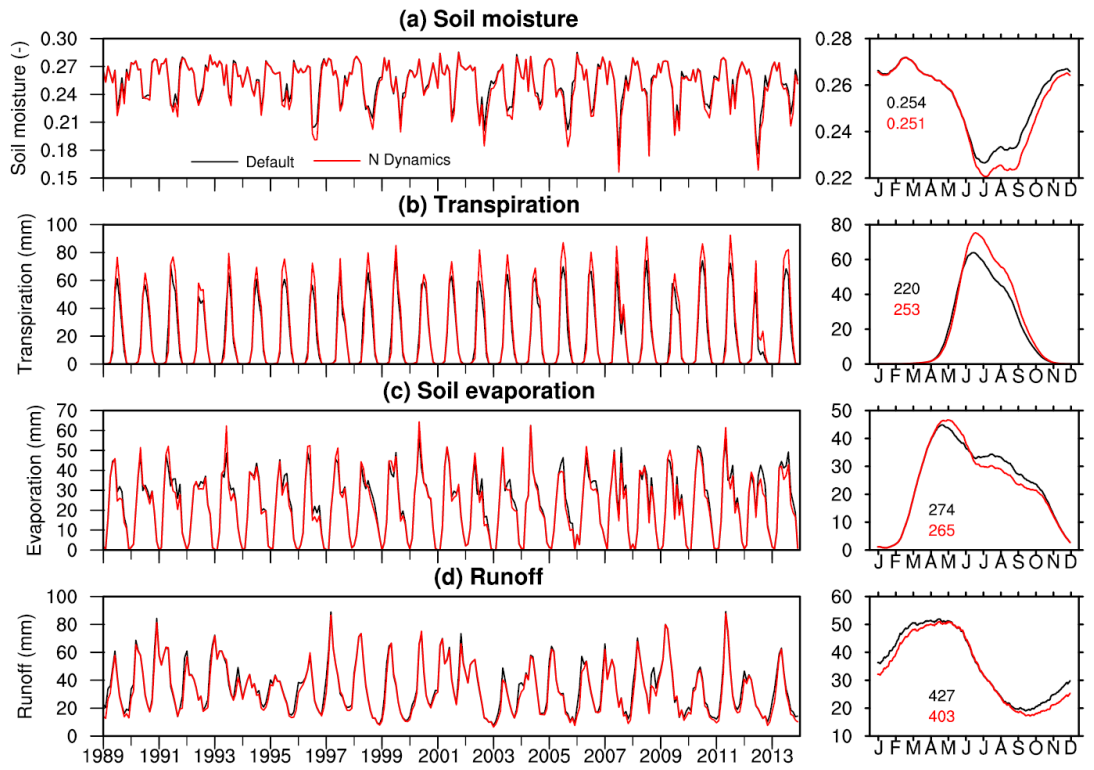

Figure 7. Same as Fig. 6 except for (a) soil moisture, (b) transpiration, (c) soil evaporation, and (d) runoff.

\subsection{Impacts of nitrogen fertilizer application}

Observed $\mathrm{N}$ fertilizer application data are used in this study. However, this type of data is not always available, especially when models are applied in large regions. Often we only know the approximate amount of $\mathrm{N}$ fertilizer applied, without information on the exact dates. To guide the future largescale application of this model, two additional experiments are run: (1) $\mathrm{N}$ fertilizer is applied on 20 June every year, and
(2) $\mathrm{N}$ fertilizer is applied on 15 April every year. The first experiment is designed because in this site a large amount of $\mathrm{N}$ fertilizer is applied mostly during mid-June and early July. Other dates are also reported in the literature; therefore, we use 15 April as another example. Both experiments use the same amount of $\mathrm{N}$ fertilizer as in the management $\log$, which on average is $7.8 \mathrm{~g} \mathrm{~N} \mathrm{~m}^{-2} \mathrm{yr}^{-1}$.

Figure 8 shows comparison of some of the most relevant results between the two experiments and the one (real) with 

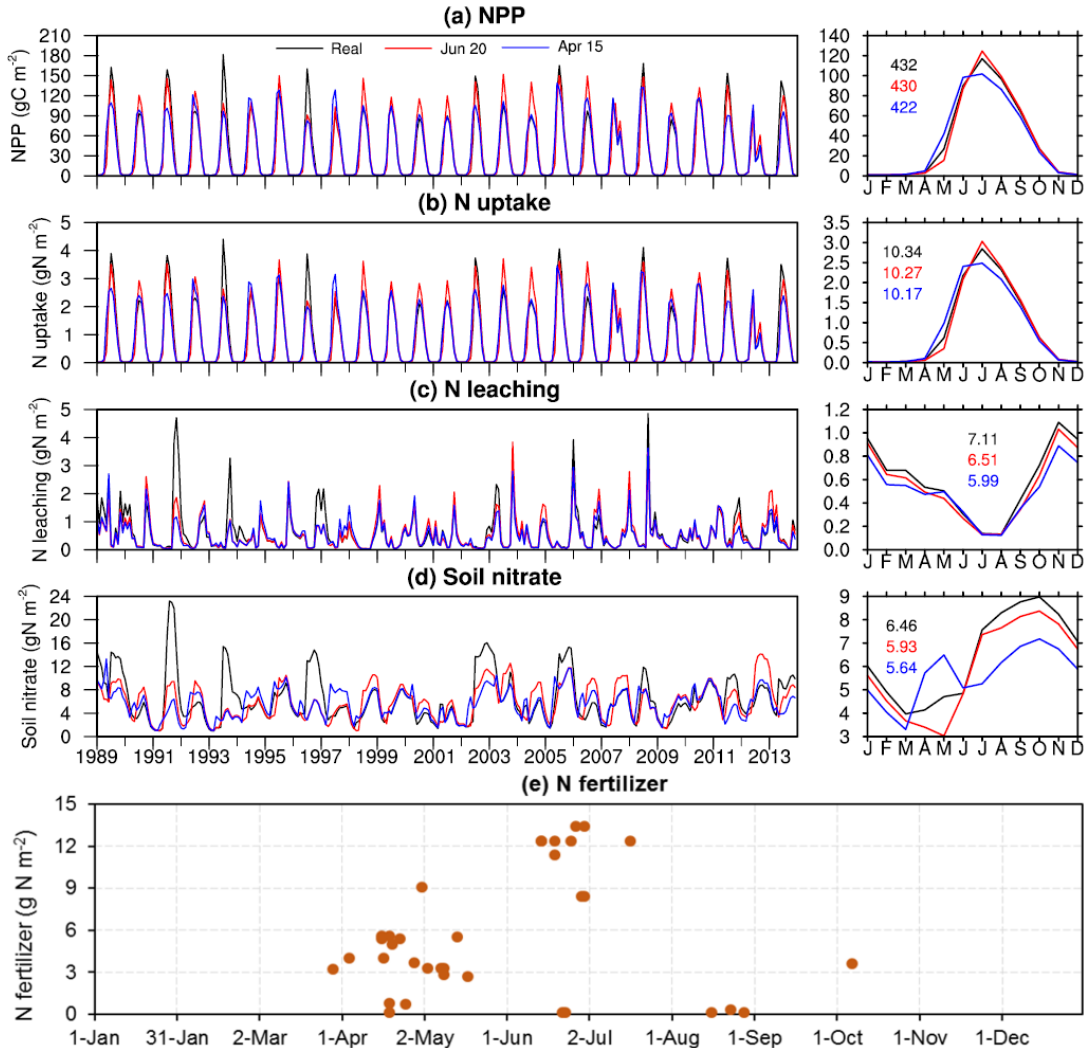

Figure 8. (left column) Monthly and (right column) climatologically seasonal cycle of model-simulated (a) NPP, (b) N uptake, (c) N leaching, and (d) soil nitrate with different dates for $\mathrm{N}$ fertilization: real, 20 June, and 15 April. The values in the right column indicate annual mean for each term (black: real; red: 20 June; blue: 15 April). (e) Actual nitrogen fertilizer application amounts and dates as recorded in the agronomic $\log$.

recorded dates and amount of $\mathrm{N}$ fertilizer application. Despite the different application time, the two experiments produce very consistent NPP with the real case. The 20 June experiment is much closer to the real case; even the seasonal variation is identical. The largest discrepancy is in 1993 and 1996. Based on the management log, in these two years, a large amount of $\mathrm{N}$ fertilizer was applied, which resulted in much higher NPP than results from the two experiments. Since 15 April is much earlier than the primary fertilizer application dates, NPP from this experiment is flattened out through the year. This also confirms the statement in Sect. 3.5 that later $\mathrm{N}$ fertilizer applications delay plant growth. Simulated $\mathrm{N}$ uptake from both experiments shows exactly the same story as NPP.

The simulated $\mathrm{N}$ leaching shows the opposite pattern to NPP. The default simulation produces the highest leaching, followed by the 20 June experiment and then the 15 April experiment. This is very likely because the fertilizer application dates are closer to the flood season for the former two cases and the chance of fertilized $\mathrm{N}$ being flashed out is higher. The difference in $\mathrm{N}$ fertilization dates also clearly affects the simulations of total soil nitrate. In the 20 June experiment, soil nitrate reaches the lowest level in May because no $\mathrm{N}$ fertil- izer is applied before 20 June. In the default case, $\mathrm{N}$ fertilizer can actually be applied as early as April, but with a smaller amount before mid-June, which prevents the soil nitrate concentration from getting too low. Besides a large amount of $\mathrm{N}$ fertilizer applied in later months, the other reason that the default simulation reaches the highest concentration of soil nitrate is because it produces higher NPP, which can be returned to soil for decomposition.

Overall, the default simulation grows better plants (higher NPP) because N fertilizer is applied based on expert judgment of plants' demand. At the same time, however, it produces more $\mathrm{N}$ leaching than the two experiments, which is significant (insignificant) with respect to the 15 April (20 June) experiment at $90 \%$ confidence level. The experiment with closer dates of $\mathrm{N}$ fertilizer application to reality can better reproduce the $\mathrm{N}$ dynamics in observation. Therefore, although we cannot always know the exact dates of $\mathrm{N}$ fertilizer application, a survey on this can help to improve model simulation. 
(a) Actual amount of uptake

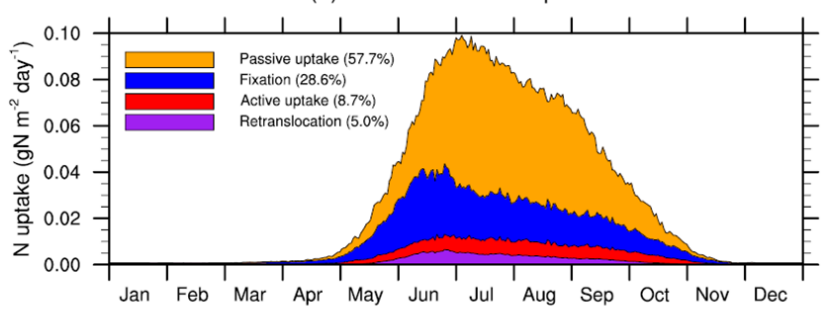

(b) Percentage of total uptake

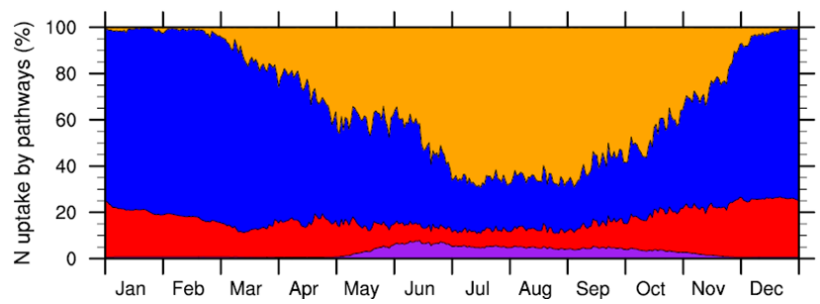

Figure 9. Daily climatology (1989-2013) of nitrogen uptake by pathways expresses as (a) actual amount of uptake and (b) percentage of total uptake.

\subsection{Analysis of nitrogen uptake}

As described in Sect. 2.2.1, plants can get $\mathrm{N}$ for growth from four pathways: passive uptake, active uptake, fixation, and retranslocation, and the last three require $\mathrm{C}$ costs. Figure 9 shows the actual $\mathrm{N}$ uptake from these pathways and their percentages of contribution to the total $\mathrm{N}$ uptake. Passive uptake is the dominant pathway, which contributes $57.7 \%$ of the total $\mathrm{N}$ uptake. Fixation, active uptake, and retranslocation contribute $28.6,8.7$, and $5.0 \%$, respectively. This contrasts the results from the study by Brzostek et al. (2014) for non-fertilized trees, in which passive uptake only accounts for a small contribution. This is understandable because the purpose of fertilization is to minimize active uptake so that more NPP can be retained for crop growth. As demonstrated in Timlin et al. (2009), a higher fertilization rate results in a higher ratio of $\mathrm{N}$ uptake in transpiration to total $\mathrm{N}$ uptake. On the one hand, fertilization maintains soil nitrate concentration at high level. On the other hand, higher NPP for crop growth in turn results in higher LAI and thus higher transpiration. During peak growing season, therefore, plants receive a large amount of $\mathrm{N}$ under the combination of high transpiration and high soil nitrate concentration. During other periods, biological $\mathrm{N}$ fixation dominates.

\subsection{Analysis of major soil nitrate fluxes}

The soil nitrate storage with time is an outcome of the variations in incoming and outgoing fluxes. Besides $\mathrm{N}$ fertilizer and atmospheric deposition, humus mineralization and residue decomposition are the two major incoming fluxes. Because $\mathrm{N}$ fertilizer is a jumping behavior and atmospheric deposition is a relatively small fraction in this study

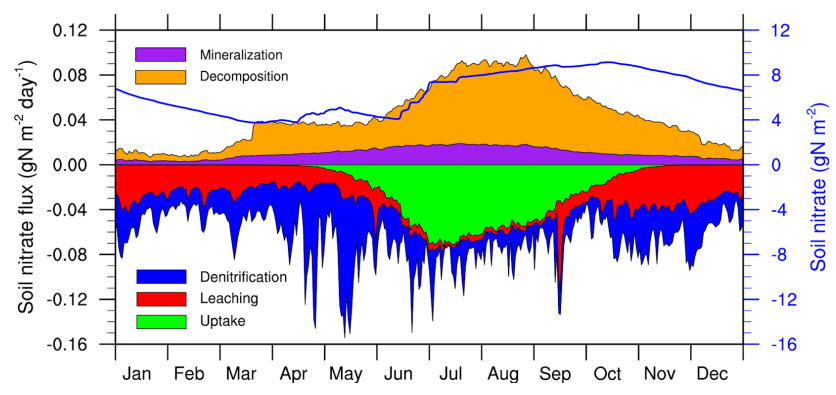

Figure 10. Daily climatology of the soil nitrate (blue solid line) and some major fluxes (color label bars) going in (humus mineralization and residue decomposition) and out (plant uptake, nitrate leaching, and denitrification) of the soil nitrate pool.

$\left(\sim 1.5 \mathrm{gN} \mathrm{m}^{-2} \mathrm{yr}^{-1}\right)$, they are not analyzed here. The major outgoing fluxes are denitrification, leaching, and plant uptake.

Figure 10 shows the seasonal variation of the above major fluxes. During the growing season, $\mathrm{N}$ fertilizer provides an important role in meeting the plant $\mathrm{N}$ demand; however, residue decomposition still makes the largest contribution and is the dominant factor responsible for the increase in total soil nitrate. During the non-growing season, a large amount of $\mathrm{N}$ is lost through denitrification and $\mathrm{N}$ leaching. However, when it reaches the peak growing season, plants consume a large fraction of soil nitrate, which leaves very little for denitrification and leaching. $\mathrm{N}$ leaching is mostly associated with the timing and intensity of precipitation. Denitrification is also associated with precipitation, but it is directly related to the soil water content. High denitrification rate occurs during high soil water content, especially during water logging.

\section{Conclusions}

In this study, a dynamic N model is coupled into Noah-MP by incorporating FUN's strength in plant $\mathrm{N}$ uptake and SWAT's strength in soil $\mathrm{N}$ cycling and agricultural management.

We evaluated the new model at KBS that provides goodquality, long-term observed $\mathrm{N}$ and ecological data. The model-simulated soil moisture is consistent with observation, which shows that Noah-MP provides a good water environment for the $\mathrm{N}$ cycling. The simulated concentrations of soil nitrate and $\mathrm{N}$ leaching from soil bottom also compare well with observations. Although the model does not simulate some peaks well, especially for $\mathrm{N}$ leaching, the averages are very close to the observed values and the correlation coefficients are reasonable. Considering the wide spread of the range error bars defined by the measurements at the six replicates, the model shows high skills in capturing the major $\mathrm{N}$ flux/state variables. The significant improvement of annual NPP simulation demonstrates that the N limitation effect on plant growth is well represented in the model. 
Moreover, the addition of $\mathrm{N}$ dynamics in Noah-MP improves the modeling of the carbon and water cycles. Compared to the default Noah-MP, NPP simulations are improved significantly, in terms of consistent averages and much higher correlation coefficients with observation. The temporal pattern of simulated ET is also improved, featuring lower ET during spring and delayed peak.

This enhancement is expected to facilitate the simultaneous predictions of weather and environment by using a fully coupled Earth modeling system.

\section{Code availability}

Noah-MP is an open-source land surface model. The model is being developed by a community led by The University of Texas at Austin. The code is archived at both http://www. ral.ucar.edu/research/land/technology/noahmp_lsm.php and http://www.jsg.utexas.edu/noah-mp. The new code implemented in this study will be made available and may be obtained by contacting the corresponding author via email.

Acknowledgements. This work is supported by the NASA grant NNX11AE42G, the National Center for Atmospheric Research Advanced Study Program, and the NASA Jet Propulsion Laboratory Strategic University Research Partnership Program. The first author would like to thank Guo-Yue Niu and Mingjie Shi for their help and the beneficial discussion with them. J. B. Fisher contributed to this research from the Jet Propulsion Laboratory, California Institute of Technology, under a contract with NASA, and through the University of California, Los Angeles. J. B. Fisher was supported by the US Department of Energy, Office of Science, Terrestrial Ecosystem Science program, and by the NSF Ecosystem Science program. X. Zhang's contribution was supported by NASA (NNH11DA001N and NNH13ZDA001N). We are grateful for the observational data from the Kellogg Biological Station, which is supported by the NSF LTER Program (DEB 1027253), by Michigan State University AgBioResearch, and by the DOE Great Lakes Bioenergy Research Center (DE-FCO2-07ER64494 and DE-ACO5-76RL01830).

Edited by: A. B. Guenther

\section{References}

Boesch, D. F., Boynton, W. R., Crowder, L. B., Diaz, R. J., Howarth, R. W., Mee, L. D., Nixon, S. W., Rabalais, N. N., Rosenberg, R., Sanders, J. G., Scavia, D., and Turner, R. E.: Nutrient enrichment drives Gulf of Mexico hypoxia, EOS T. Am. Geophys. Un., 90, 117-118, doi:10.1029/2009eo140001, 2009.

Bonan, G. B.: Atmosphere-biosphere exchange of carbon dioxide in boreal forests, J. Geophys. Res., 96, 7301-7312, 1991.

Bonan, G. B. and Levis, S.: Quantifying carbon-nitrogen feedbacks in the Community Land Model (CLM4), Geophys. Res. Lett., 37, L07401, doi:10.1029/2010GL042430, 2010.

Boyer, E. W., Howarth, R. W., Galloway, J. N., Dentener, F. J., Green, P. A., and Vorosmarty, C. J.: Riverine nitrogen export from the continents to the coasts, Global Biogeochem. Cy., 20, GB1S91, doi:10.1029/2005GB002537, 2006.

Brzostek, E. R., Fisher, J. B., and Phillips, R. P.: Modeling the carbon cost of plant nitrogen acquisition: Mycorrhizal trade-offs and multipath resistance uptake improve predictions of retranslocation, J. Geophys. Res., 119, 1684-1697, 2014.

Cai, X., Yang, Z.-L., David, C. H., Niu, G.-Y., and Rodell, M.: Hydrological evaluation of the Noah-MP land surface model for the Mississippi River Basin, J. Geophys. Res., 119, 23-38, 2014a.

Cai, X., Yang, Z.-L., Xia, Y., Huang, M., Wei, H., Leung, L. R., and Ek, M. B.: Assessment of simulated water balance from Noah, Noah-MP, CLM, and VIC over CONUS using the NLDAS test bed, J. Geophys. Res., 119, 13751-13770, 2014b.

Clark, D. B., Mercado, L. M., Sitch, S., Jones, C. D., Gedney, N., Best, M. J., Pryor, M., Rooney, G. G., Essery, R. L. H., Blyth, E., Boucher, O., Harding, R. J., Huntingford, C., and Cox, P. M.: The Joint UK Land Environment Simulator (JULES), model description - Part 2: Carbon fluxes and vegetation dynamics, Geosci. Model Dev., 4, 701-722, doi:10.5194/gmd-4-701-2011, 2011.

Clark, M. P., Kavetski, D., and Fenicia, F.: Pursuing the method of multiple working hypotheses for hydrological modeling, Water Resour. Res., 47, W09301, doi:10.1029/2010wr009827, 2011.

Conley, D. J., Paerl, H. W., Howarth, R. W., Boesch, D. F., Seitzinger, S. P., Havens, K. E., Lancelot, C., and Likens, G. E.: Controlling eutrophication: Nitrogen and phosphorus, Science, 323, 1014-1015, 2009.

Diaz, R. J. and Rosenberg, R.: Spreading dead zones and consequences for marine ecosystems, Science, 321, 926-929, 2008.

Dickinson, R. E., Berry, J. A., Bonan, G. B., Collatz, G. J., Field, C. B., Fung, I. Y., Goulden, M., Hoffmann, W. A., Jackson, R. B., Myneni, R., Sellers, P. J., and Shaikh, M.: Nitrogen controls on climate model evapotranspiration, J. Climate, 15, 278-295, 2002.

Donner, S. D. and Scavia, D.: How climate controls the flux of nitrogen by the Mississippi River and the development of hypoxia in the Gulf of Mexico, Limnol. Oceanogr., 52, 856-861, 2007.

Fisher, J. B., Sitch, S., Malhi, Y., Fisher, R. A., Huntingford, C., and Tan, S. Y.: Carbon cost of plant nitrogen acquisition: A mechanistic, globally applicable model of plant nitrogen uptake, retranslocation, and fixation, Global Biogeochem. Cy., 24, Gb1014, doi:10.1029/2009gb003621, 2010.

Fisher, J. B., Badgley, G., and Blyth, E.: Global nutrient limitation in terrestrial vegetation, Global Biogeochem. Cy., 26, Gb3007, doi:10.1029/2011gb004252, 2012.

Fowler, D., Coyle, M., Skiba, U., Sutton, M. A., Cape, J. N., Reis, S., Sheppard, L. J., Jenkins, A., Grizzetti, B., Galloway, J. N., Vitousek, P., Leach, A., Bouwman, A. F., Butterbach-Bahl, K., Dentener, F., Stevenson, D., Amann, M., and Voss, M.: The global nitrogen cycle in the twenty-first century, Philos. T. R. Soc. B, 368, 20130164, doi:10.1098/Rstb.2013.0164, 2013.

Gruber, N. and Galloway, J. N.: An Earth-system perspective of the global nitrogen cycle, Nature, 451, 293-296, 2008.

Houlton, B. Z., Wang, Y. P., Vitousek, P. M., and Field, C. B.: A unifying framework for dinitrogen fixation in the terrestrial biosphere, Nature, 454, 327-334, 2008.

Howarth, R. W., Swaney, D. P., Boyer, E. W., Marino, R., Jaworski, N., and Goodale, C.: The influence of climate on average nitrogen export from large watersheds in the Northeastern United States, Biogeochemistry, 79, 163-186, 2006. 
Knops, J. M. H. and Tilman, D.: Dynamics of soil nitrogen and carbon accumulation for 61 years after agricultural abandonment, Ecology, 81, 88-98, 2000.

Komatsu, E., Fukushima, T., and Harasawa, H.: A modeling approach to forecast the effect of long-term climate change on lake water quality, Ecol. Model., 209, 351-366, 2007.

Kronvang, B., Behrendt, H., Andersen, H. E., Arheimer, B., Barr, A., Borgvang, S. A., Bouraoui, F., Granlund, K., Grizzetti, B., Groenendijk, P., Schwaiger, E., Hejzlar, J., Hoffmann, L., Johnsson, H., Panagopoulos, Y., Lo Porto, A., Reisser, H., Schoumans, O., Anthony, S., Silgram, M., Venohr, M., and Larsen, S. E.: Ensemble modelling of nutrient loads and nutrient load partitioning in 17 European catchments, J. Environ. Monitor., 11, 572-583, 2009.

National Research Council: Clean coastal waters: understanding and reducing the effects of nutrient pollution, National Academy of Sciences, Washington, D.C., 2000.

Neitsch, S. L., Arnold, J. G., Kiniry, J. R., and Williams, J. R.: Soil and Water Assessment Tool theoretical documentation version 2009, Texas Water Resources Institute, Texas A\&M University, College Station, TXTechnical Report No. 406, 2011.

Niu, G.-Y., Yang, Z.-L., Mitchell, K. E., Chen, F., Ek, M. B., Barlage, M., Kumar, A., Manning, K., Niyogi, D., Rosero, E., Tewari, M., and Xia, Y. L.: The community Noah land surface model with multiparameterization options (Noah-MP): 1. Model description and evaluation with local-scale measurements, J. Geophys. Res., 116, D12109, doi:10.1029/2010jd015139, 2011.

Oleson, K. W., Lawrence, D. M., Bonan, G. B., Drewniak, B., Huang, M., Koven, C. D., Levis, S., Li, F., Riley, W. J., Subin, Z. M., Swenson, S. C., Thornton, P. E., Bozbiyik, A., Fisher, R., Heald, C. L., Kluzek, E., Lamarque, J.-F., Lawrence, P. J., Leung, L. R., Lipscomb, W., Muszala, S., Ricciuto, D. M., Sacks, W., Sun, Y., Tang, J., and Yang, Z.-L.: Technical description of version 4.5 of the Community Land Model (CLM), National Center for Atmospheric Research, Boulder, ColoradoNCAR Technical Note NCAR/TN-503+STR, 434 pp., 2013.

Prince, S. D., Haskett, J., Steininger, M., Strand, H., and Wright, R.: Net primary production of US Midwest croplands from agricultural harvest yield data, Ecol. Appl., 11, 1194-1205, 2001.

Rasmussen, R., Ikeda, K., Liu, C. H., Gochis, D., Clark, M., Dai, A. G., Gutmann, E., Dudhia, J., Chen, F., Barlage, M., Yates, D., and Zhang, G.: Climate change impacts on the water balance of the Colorado headwaters: High-resolution regional climate model simulations, J. Hydrometeorol., 15, 1091-1116, 2014.

Running, S. W. and Coughlan, J. C.: A general model of forest ecosystem processes for regional applications I. Hydrologic balance, canopy, Ecol. Model., 42, 125-154, 1988.

Scanlon, B. R., Reedy, R. C., and Bronson, K. F.: Impacts of land use change on nitrogen cycling archived in semiarid unsaturated zone nitrate profiles, southern High Plains, Texas, Environ. Sci. Technol., 42, 7566-7572, 2008.

Schoumans, O. F., Silgram, M., Groenendijk, P., Bouraoui, F., Andersen, H. E., Kronvang, B., Behrendt, H., Arheimer, B., Johnsson, H., Panagopoulos, Y., Mimikou, M., Lo Porto, A., Reisser, H., Le Gall, G., Barr, A., and Anthony, S. G.: Description of nine nutrient loss models: capabilities and suitability based on their characteristics, J. Environ. Monitor., 11, 506-514, 2009.
Shi, M., Fisher, J. B., Brzostek, E. R., and Phillips, R. P.: Carbon cost of plant nitrogen acquisition: global carbon cycle impact from an improved plant nitrogen cycle in the Community Land Model, Global Change Biol., doi:10.1111/gcb.13131, in press, 2016.

Thornton, P. E., Lamarque, J. F., Rosenbloom, N. A., and Mahowald, N. M.: Influence of carbon-nitrogen cycle coupling on land model response to $\mathrm{CO}_{2}$ fertilization and climate variability, Global Biogeochem. Cy., 21, Gb4018, doi:10.1029/2006gb002868, 2007.

Timlin, D., Kouznetsov, M., Fleisher, D., Kim, S.-H., and Reddy, V. R.: Simulation of nitrogen demand and uptake in potato using a carbon-assimilation approach, in: Quantifying and Understanding Plant Nitrogen Uptake for Systems Modeling, edited by: Ma, L., Ahuja, L. R., and Bruulsema, T. W., CRC Press, 2009.

Wang, Y. P., Houlton, B. Z., and Field, C. B.: A model of biogeochemical cycles of carbon, nitrogen, and phosphorus including symbiotic nitrogen fixation and phosphatase production, Global Biogeochem. Cy., 21, Gb1018, doi:10.1029/2006gb002797, 2007.

West, T. O., Brandt, C. C., Baskaran, L. M., Hellwinckel, C. M., Mueller, R., Bernacchi, C. J., Bandaru, V., Yang, B., Wilson, B. S., Marland, G., Nelson, R. G., Ugarte, D. G. D. L. T., and Post, W. M.: Cropland carbon fluxes in the United States: increasing geospatial resolution of inventory-based carbon accounting, Ecol. Appl., 20, 1074-1086, 2010.

Williams, J. R.: The EPIC model, in: Computer models of watershed hydrology, edited by: Singh, V. P., Water Resources Publications, Highlands Ranch, CO, 1995.

Xia, Y. L., Mitchell, K., Ek, M., Sheffield, J., Cosgrove, B., Wood, E., Luo, L. F., Alonge, C., Wei, H. L., Meng, J., Livneh, B., Lettenmaier, D., Koren, V., Duan, Q. Y., Mo, K., Fan, Y., and Mocko, D.: Continental-scale water and energy flux analysis and validation for the North American Land Data Assimilation System project phase 2 (NLDAS-2): 1. Intercomparison and application of model products, J. Geophys. Res., 117, D03109, doi:10.1029/2011jd016048, 2012.

Yang, X. J., Wittig, V., Jain, A. K., and Post, W.: Integration of nitrogen cycle dynamics into the Integrated Science Assessment Model for the study of terrestrial ecosystem responses to global change, Global Biogeochem. Cy., 23, GB4029, doi:10.1029/2009gb003474, 2009.

Yang, Z.-L., Niu, G.-Y., Mitchell, K. E., Chen, F., Ek, M. B., Barlage, M., Longuevergne, L., Manning, K., Niyogi, D., Tewari, M., and Xia, Y. L.: The community Noah land surface model with multiparameterization options (Noah-MP): 2. Evaluation over global river basins, J. Geophys. Res., 116, D12110, doi:10.1029/2010jd015140, 2011. 